\title{
Usulan Perbaikan Proses Bisnis Departemen J20 di PT Indorama Synthetics Tbk dengan Menggunakan Metode Business Process Reengineering
}

\author{
Dedy Setyo Oetomo ${ }^{1}$, Rizky Fajar Ramdhani ${ }^{2 *}$ \\ ${ }^{1,2,3}$ Program Studi Teknik Industri, STT Wastukancana \\ Jl. Alternative Bukit Indah, Kabupaten Purwakarta, Jawa Barat 41151, Indonesia \\ 11dedy@stt-wastukancana.ac.id \\ 2*rizky@stt-wastukancana.ac.id

\section{Proposed Improvement of the J20 Department's Business Process at PT Indorama Synthetics Tbk Using the Business Process Reengineering Method}

Dikirimkan : 04, 2021. Diterima : 08, 2021. Dipublikasikan : 09, 2021.

\begin{abstract}
The business process of the J20 production department is currently experiencing obstacles in terms of information delivery, production report, maintenance report, and problem information that causes decision making is often irrelevant. This is due to the use of paper media with a long bureaucratic flow so that the cycle time becomes inefficient. This study used business process reengineering, modeling business process in business process modeling notation (BPMN), and supporting research problem analysis used fishbone diagram. The result showed changes in a process flow, job desk, unit elimination, and proposed design of information systems in the form of application software as a solution to the problems studied, so that it is expected to obtain process time efficiency of $65.1 \%$ and cycle time of $99.2 \%$ of the previous total time.

Keywords - Proposed Business Process Improvement, Business Process Production Department, Business Process Reengineering (BPR)

Abstrak - Proses bisnis departemen produksi J20 saat ini mengalami hambatan dalam hal penyampaian informasi, laporan hasil produksi, laporan maintenance, serta informasi problem, yang menyebabkan pengambilan keputusan sering kali terjadi bias. Hal ini di sebabkan oleh penggunaan media kertas dengan alur birokrasi yang panjang sehingga waktu siklus menjadi tidak efisien. Pada penelitian ini digunakan metode Business Process Reengineering, dengan memodelkan bisnis proses dalam Business Process Modelling Notation $(B P M N)$, serta pendukung analisa masalah penelitian digunakan diagram tulang ikan. Hasil penelitian menunjukan adanya perubahan alur proses, jobdesk, eliminasi unit, serta usulan perancangan sistem informasi berupa software aplikasi sebagai solusi dari permasalahan yang diteliti, sehingga diharapkan dapat diperoleh efisiensi waktu proses sebesar $65,1 \%$ dan waktu siklus sebesar 99,2\% dari total waktu sebelumnya.
\end{abstract}


Kata kunci- Usulan Perbaikan Proses Bisnis, Proses Bisnis Departemen Produksi, Business Process Reengineering (BPR)

\section{PENDAHULUAN}

Perubahan dalam dunia industri sangat pesat, intensitas upaya pemasaran bertahun-tahun telah mensegmentasi pasar secara terus menerus telah menimbulkan tekanan atas kegiatan-kegiatan operasional, sehingga banyak perusahaan mempertahankan dominasinya dengan melakukan perampingan operasi besar-besaran melalui rekayasa ulang proses bisnis di seluruh mata rantai pasokan. Rekayasa ulang proses bisnis memaksa para pemimpin perusahaan untuk mengambil ancangan radikal dalam memposisikan, mengorganisasikan bisnis mereka dari hal apa yang harus dikerjakan menjadi hal yang dapat dikerjakan. Seringkali pemimpin perusahaan dalam melakukan rekayasa ulang proses bisnis, menanjak dari jalur teknis ketimbang dari jalur keuangan atau pemasaran. Reaksi seketika prinsip organisasi berdasarkan proses ini adalah semakin sederhana makin baik, semakin langsung kontak antar bagian, semakin cepat ditanggapi. [1]

Departemen J20 merupakan departemen produksi, salah satu departemen bagian dari cotton unit pada PT. Indorama Synthetics Tbk, Purwakarta yang memproduksi benang sebagai produk jadi. Proses bisnis yang dijalankan saat ini, banyak pihak yang terlibat denga alur birokasi yang panjang serta penggunaan kertas sebagai surat jalan maupun dokumentasi proses, sehingga menimbulkan inefisieni waktu. Diantaranya, proses pelaporan produksi, yang merupakan hasil catatan (Hand book) operator produksi setiap shift, kemudian dilakukan print oleh bagian office dan diserahkan ke manager, proses ini memiliki siklus waktu per 24 jam. Kemudian pada proses pelaporan maintenance, tidak memiliki waktu baku dalam melaporkan, dalam satu minggu, pelaporan bisa terjadi dua bahkan satu kali dalam satu minggu. Seluruh laporan di print ulang oleh bagian office dan diserahkan kembali ke bagian maintenance. Proses lainya ialah proses problem info, dimana operator memberi informasi ke leader untuk disampaikan ke bagian maintenance dan bagian $R \& D$, begitu pun sebaliknya, aliran informasi terkait hasil quality serta hasil check atau settup.

Berdasarkan uraian tersebut, maka pada penelitian ini diajukan untuk usulan perbaikan proses bisnis dengan menggunakan metode business process reengineering, agar dapat mengidentifikasi peluang untuk mengubah kinerja operasional, sehingga keberlangsungan bisnis dapat memperoleh mutu yang baik, kecepatan, serta fleksibilitas melalui peningkatan produktivitas.[2]

\section{Metodologi Penelitian}

Pada penelitian ini, lingkup yang diteliti ialah pada departemen J20, dengan melakukan observasi serta wawancara dengan seluruh karyawan terkait proses bisnis saat ini. Temuan seluruh proses bisnis existing dimodelkan dalam business process modelling natation (BPMN)

Existing[3]. Diagram tulang ikan digunakan sebagai alat untuk identifikasi sumber masalah [4]. Setelah bottleneck teridentifikasi dalam proses bisnis saat ini, langkah selanjutnya ialah memodelkan proses bisnis usulan, dengan membuat design user interface sebagai tools dari perancangan software aplikasi untuk mengatasi permasalahan pada penelitian ini, sehingga dari rekap total waktu proses bisnis saat ini dibandingkan dengan total waktu proses yang diharapkan, terdapat kesenjangan waktu proses yang radikal untuk perbaikan proses secara operasional.[2]

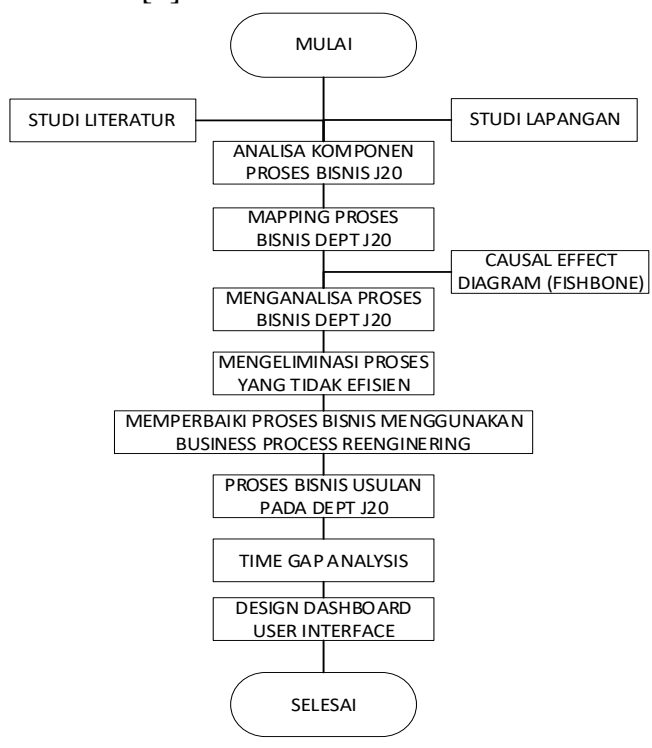

Gambar 1. Tahapan Penelitian

\section{HASIL PENELITIAN}

\section{A. Proses Bisnis Existing}

$B P M N$ secara rinci memberikan gambaran umum tentang potensi penggunaan model formal dengan fokus khusus pada validasi dan verifikasi diagram proses.[5] proses bisnis existing departemen J20 ditunjukan pada gambar 2. 
Jurnal Media

Teknik dan

Sistem Industri

B. Rekapitulasi waktu proses bisnis existing. ditunjukan pada Tabel I. dan siklus proses pada Tabel II.

TABEL I

REKAPITULASI TOTAL WAKTU EXISTING

\begin{tabular}{|c|c|c|}
\hline Process & Dokumen & Time \\
\hline $\begin{array}{l}\text { Persetujuan plan } \\
\text { produksi }\end{array}$ & Issue/indent & $10^{\prime}$ \\
\hline $\begin{array}{l}\text { Membuat dan } \\
\text { mengirimkan flat } \\
\text { info, issue, indent }\end{array}$ & $\begin{array}{l}\text { Flat info, } \\
\text { issue, indent }\end{array}$ & $7^{\prime}$ \\
\hline $\begin{array}{l}\text { Print dan } \\
\text { menyerahkan flat } \\
\text { info }\end{array}$ & $\begin{array}{l}\text { Flat info, } \\
\text { issue, indent }\end{array}$ & $10^{\prime}$ \\
\hline $\begin{array}{c}\text { Print dan } \\
\text { tandatangan form } \\
\text { issue, indent }\end{array}$ & $\begin{array}{l}\text { Flat info, } \\
\text { issue, indent }\end{array}$ & $7^{\prime}$ \\
\hline $\begin{array}{c}\text { Print dan } \\
\text { menyerahkan } \\
\text { label }\end{array}$ & Label & $10^{\prime}$ \\
\hline $\begin{array}{l}\text { Menyerahkan } \\
\text { issue/indent }\end{array}$ & Issue/indent & $8^{\prime}$ \\
\hline Check bahan baku & Issue & $5^{\prime}$ \\
\hline $\begin{array}{c}\text { Check } \\
\text { barang/sparepart }\end{array}$ & Issue & $7^{\prime}$ \\
\hline $\begin{array}{c}\text { Koordinasi quality } \\
\text { check daily, } \\
\text { weekly }\end{array}$ & Cont (file) & $5^{\prime}$ \\
\hline $\begin{array}{l}\text { Menerima flat } \\
\text { informasi }\end{array}$ & Flat info & $1^{\prime}$ \\
\hline $\begin{array}{c}\text { Menerima } \\
\text { interuksi dan } \\
\text { menempelkan flat } \\
\text { info di mesin }\end{array}$ & Flat info & $5^{\prime}$ \\
\hline $\begin{array}{c}\text { Memberi info ke } \\
\text { operator }\end{array}$ & Flat info & $5^{\prime}$ \\
\hline $\begin{array}{c}\text { Informasi } \\
\text { setup/maintenance }\end{array}$ & & $2^{\prime}$ \\
\hline $\begin{array}{l}\text { Koordinasi } \\
\text { sample }\end{array}$ & Lot & $2^{\prime}$ \\
\hline $\begin{array}{l}\text { Mencatat laporan } \\
\text { (operator) }\end{array}$ & $\begin{array}{c}\text { Log, hank, } \\
\text { stopage }\end{array}$ & $7^{\prime}$ \\
\hline $\begin{array}{c}\text { Mencatat laporan } \\
\text { (leader) }\end{array}$ & $\log$ & $3^{\prime}$ \\
\hline $\begin{array}{c}\text { Menyimpan } \\
\text { sparepart }\end{array}$ & & $5^{\prime}$ \\
\hline $\begin{array}{c}\text { Mencatat laporan } \\
\text { (maintenance) }\end{array}$ & Log, schadule & $5^{\prime}$ \\
\hline $\begin{array}{c}\text { Serah terima } \\
\text { dengan shift } \\
\text { berikutnya }\end{array}$ & $\begin{array}{l}\text { log, hank, } \\
\text { stopage }\end{array}$ & $10^{\prime}$ \\
\hline $\begin{array}{c}\text { Office mengambil } \\
\text { laporan, entry ke } \\
\text { sistem }\end{array}$ & $\begin{array}{l}\text { Hank, } \\
\text { stopage }\end{array}$ & $10^{\prime}$ \\
\hline $\begin{array}{c}\text { Entry schedule } \\
\text { maintenance } \\
\text { (office) }\end{array}$ & Schedule & $5^{\prime}$ \\
\hline $\begin{array}{l}H O S \text { menerima } \\
\text { laporan }\end{array}$ & Log book & $5^{\prime}$ \\
\hline $\begin{array}{c}\text { HOS menerima } \\
\text { laporan, dan } \\
\text { informasi } \\
\text { kebutuhan } \\
\text { sparepart }\end{array}$ & Log book & $7^{\prime}$ \\
\hline Laporan ke $H O D$ & Report & $15^{\prime}$ \\
\hline Total Time & $146^{\prime}$ & \\
\hline
\end{tabular}

TABEL II

WAKTU SIKLUS EXISTING

\begin{tabular}{ccc}
\hline Process & Dokumen & Time \\
\hline $\begin{array}{c}\text { Siklus informasi } \\
\text { problem }\end{array}$ & $10^{\prime}$ \\
Siklus laporan produksi & $\begin{array}{c}\text { Hank, } \\
\text { stopage, } \\
\text { logbook } \\
\text { Form } \\
\text { quality }\end{array}$ & 124 jam \\
\hline Total Time & $17^{\prime}$ \\
\hline
\end{tabular}

\section{Fishbone Diagram}

Analisa sumber masalah dikategorikan pada 6 M, setiap kategori mempunyai pengaruh satu sama lain yang dapat mengidentifikasi pengaruh sebab akibat[6]. Proses bisnis existing departemen J20, dapat diidentifikasi sumber-sumber inefisiensi proses, seperti yang ditunjukan pada gambar 3 . Berdasarkan tabel III. Keterangan indikator fisbhbone, Sumber akar masalah yang berada pada tingkat level 3 pada proses bisnis departemen produksi J20, ialah kategori man, machine, method, dan measurment. Kategori method, teridentifikasi memiliki dua akar masalah yang berada pada tingkat level 3.

TABEL III

KETERANGAN INDIKATOR FISHBONE

\begin{tabular}{cc}
\hline Indikator & Keterangan \\
\hline Kotak berwarna merah & $\begin{array}{l}\text { Masalah Level 1 (Penyebab } \\
\text { kepala ikan) } \\
\text { Masalah Level 2 (Penyebab } \\
\text { Kotak berwarna hijau }\end{array}$ \\
Kovel 1) \\
Kotak berwarna coklat & Masalah Level 3 (Penyebab \\
& Level 2) \\
\hline
\end{tabular}

\section{PEMBAHASAN}

\section{A. Proses Bisnis Usulan}

$B P R$ digunakan untuk merancang ulang proses bisnis secara fundamental, berorientasi pada proses, secara dramatis mengalami perubahan yang sama sekali baru dan radikal, dalam hal performansi kritis seperti biaya, kecepatan, fleksibilitas. [7] penelitian ini mengemukakan perubahan terhadap waktu serta fleksibilitas, tidak terhadap biaya. Proses bisnis usulan ditunjukan pada gambar 4. Dimana terjadi perubahan proses dan alur birokrasi serta kesenjangan waktu yang sangat signifikan.

\section{1). Eliminate bagian}

Terdapat 2 bagian yang perlu dilakukan eliminasi, yaitu bagian office dan leader. Dimana jobdesk pada bagian ini dapat dialihkan ke 3 bagian lainya yaitu, HOS, Operator, dan Maintenance.

\section{2). Proses yang krusial untuk diperbaik}


- Proses issue, indent barang maupun bahan baku

- Proses Flat informasi

- Proses informasi problem atau ubnormal

- Proses cek barang pesanan pada saat awal kedatangan

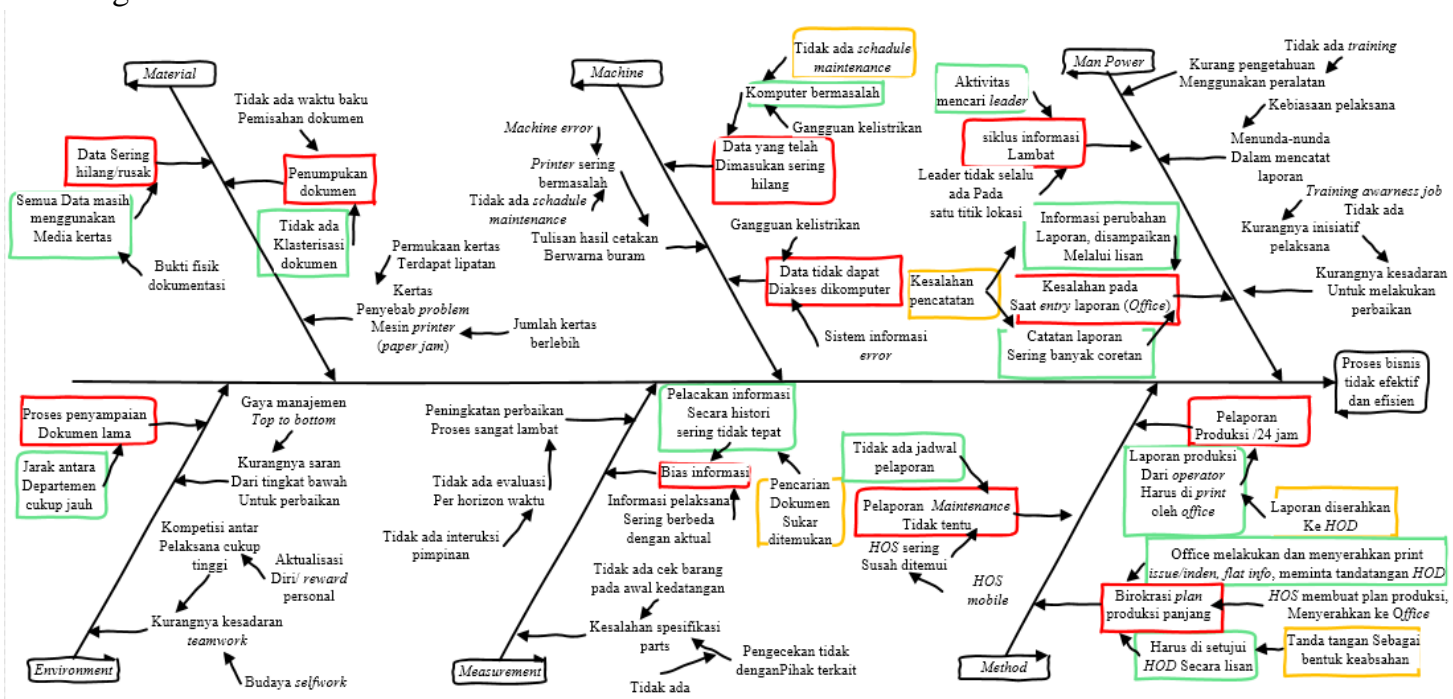

Gambar 2. Fishbone diagram proses bisnis existing

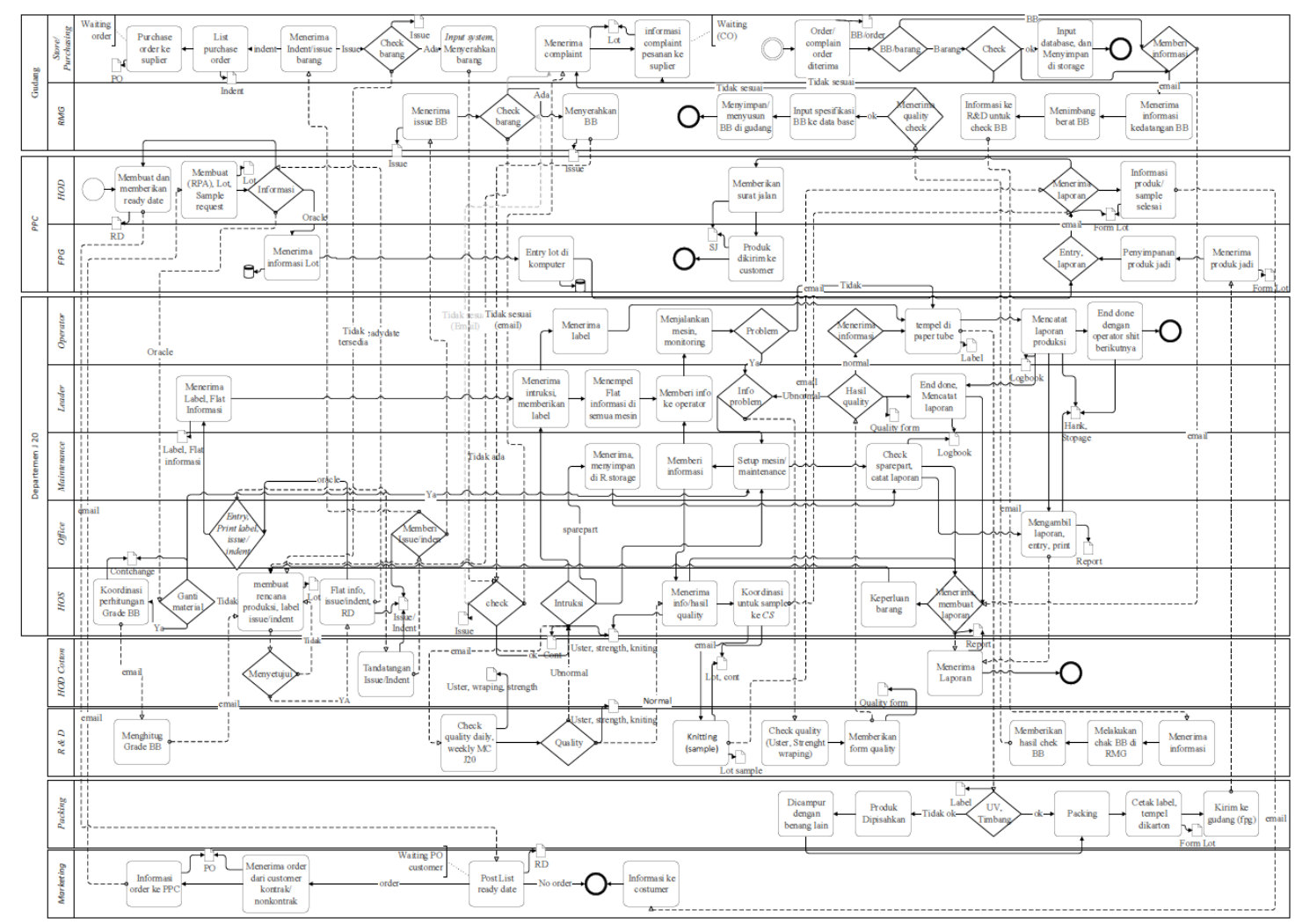

Gambar 3. Proses bisnis existing 
Jurnal Media

Teknik dan

Sistem Industri

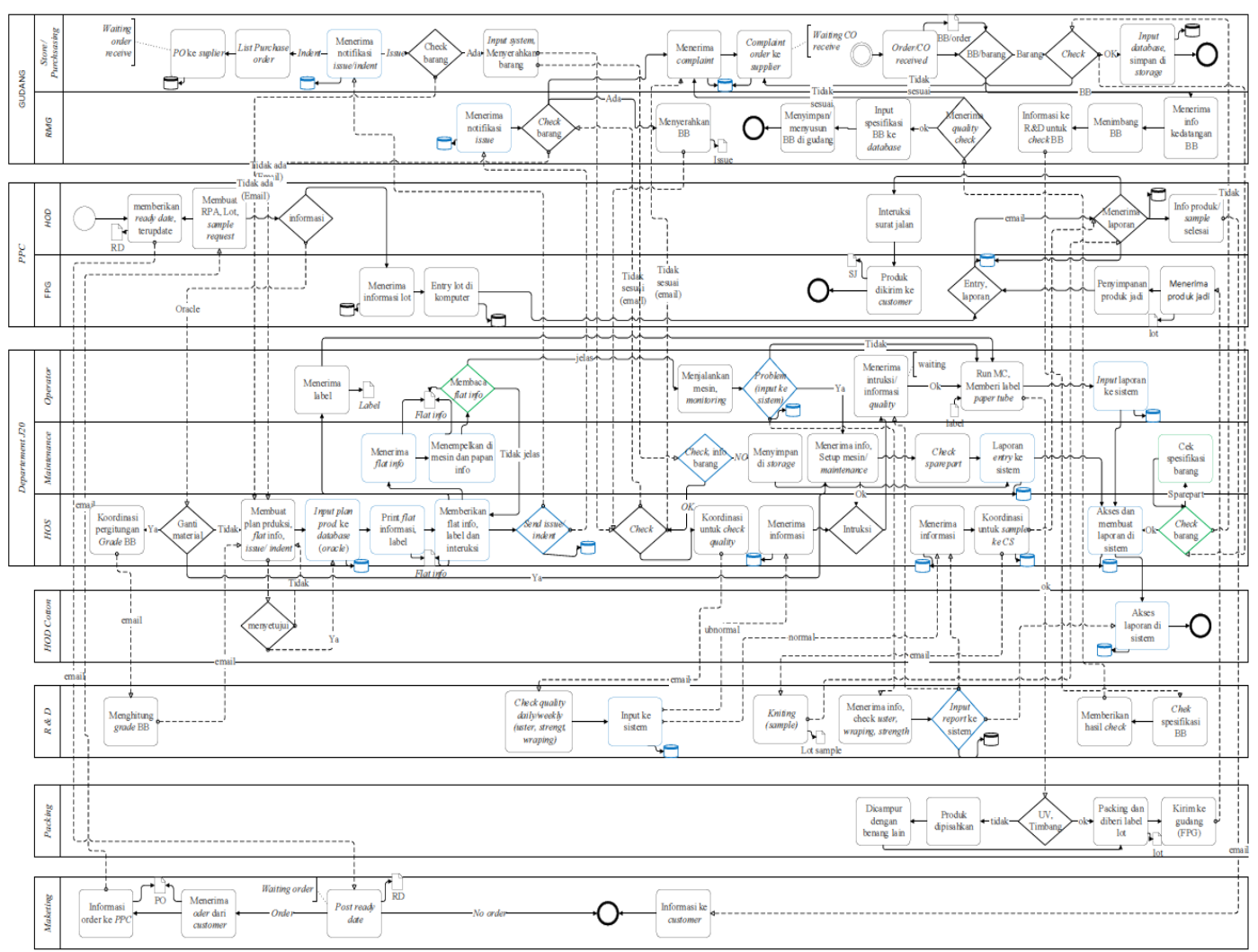

Gambar 4. Proses bisnis usulan

\section{B. Rekapitulasi waktu proses usulan}

TABEL IV

REKAPITULASI WAKTU PROSES USULAN

\begin{tabular}{|c|c|c|c|}
\hline Process & Database & Time & $\underset{k}{\text { Remar }}$ \\
\hline $\begin{array}{l}\text { Persetujuan plan } \\
\text { produksi }\end{array}$ & Issue/indent & $1^{\prime}$ & app \\
\hline $\begin{array}{c}\text { Approve issue, } \\
\text { indent }\end{array}$ & Issue, indent & $2^{\prime}$ & app \\
\hline $\begin{array}{c}\text { Print dan } \\
\text { menyerahkan flat } \\
\text { info }\end{array}$ & flat info & $3^{\prime}$ & app \\
\hline $\begin{array}{c}\text { Print dan } \\
\text { menyerahkan } \\
\text { label }\end{array}$ & & $4^{\prime}$ & Label \\
\hline $\begin{array}{c}\text { Check bahan } \\
\text { Baku }\end{array}$ & Issue/indent & $5^{\prime}$ & app \\
\hline $\begin{array}{c}\text { Check } \\
\text { barang/sparepart }\end{array}$ & Issue & $7^{\prime}$ & app \\
\hline $\begin{array}{l}\text { Koordinasi } \\
\text { quality check } \\
\text { daily, weekly }\end{array}$ & Cont Ne & $2^{\prime}$ & $a p p$ \\
\hline $\begin{array}{l}\text { Menerima flat } \\
\text { informasi }\end{array}$ & Flat info & $1^{\prime}$ & app \\
\hline $\begin{array}{l}\text { Menempelkan } \\
\text { flat info di mesin }\end{array}$ & Flat info & $2^{\prime}$ & $A p p$ \\
\hline $\begin{array}{c}\text { Membaca flat } \\
\text { info }\end{array}$ & Flat info & $2^{\prime}$ & $A p p$ \\
\hline $\begin{array}{c}\text { Informasi } \\
\text { setup/maintenanc } \\
e\end{array}$ & Info problem & $1^{\prime}$ & $A p p$ \\
\hline $\begin{array}{l}\text { Koordinasi } \\
\text { sample }\end{array}$ & Lot & $2^{\prime}$ & $A p p$ \\
\hline
\end{tabular}

\begin{tabular}{|c|c|c|c|}
\hline Process & Database & Time & $\underset{k}{R e m a r}$ \\
\hline $\begin{array}{c}\text { Entry laporan } \\
\text { (operator) }\end{array}$ & $\begin{array}{l}\text { Log, hank, } \\
\text { stopage }\end{array}$ & $3^{\prime}$ & $A p p$ \\
\hline $\begin{array}{c}\text { Update } \\
\text { sparepart }\end{array}$ & $\begin{array}{c}\text { Sparepart } \\
\text { need/use/stoc } \\
k\end{array}$ & $3^{\prime}$ & $A p p$ \\
\hline $\begin{array}{l}\text { Entry laporan } \\
\text { (maintenance) }\end{array}$ & $\begin{array}{l}\text { Log, } \\
\text { schadule }\end{array}$ & $3^{\prime}$ & $A p p$ \\
\hline $\begin{array}{c}H O S \text { akses } \\
\text { laporan }\end{array}$ & Log book & $5^{\prime}$ & app \\
\hline $\begin{array}{c}\text { HOS entry } \\
\text { laporan untuk } \\
H O D\end{array}$ & Report & $5^{\prime}$ & app \\
\hline \multicolumn{2}{|c|}{ Total Time } & $51^{\prime}$ & \\
\hline
\end{tabular}

TABEL V.

WAKTU SIKLUS USULAN

\begin{tabular}{cccc}
\hline Process & Database & Time & Remark \\
\hline $\begin{array}{c}\text { Siklus informasi } \\
\text { problem }\end{array}$ & $\begin{array}{c}\text { Problem info } \\
\text { Hank, }\end{array}$ & 2 & app \\
$\begin{array}{c}\text { Siklus laporan } \\
\text { produksi }\end{array}$ & $\begin{array}{c}\text { stopage, } \\
\text { logbook }\end{array}$ & - & app \\
$\begin{array}{c}\text { Siklus quality } \\
\text { check }\end{array}$ & Form quality & $10^{\prime}$ & app \\
\hline \multicolumn{2}{c}{ Total Time } & $\mathbf{1 2}$ & \\
\hline
\end{tabular}

\section{Software aplikasi}

Pada penelitian ini, penulis hanya sampai pada tahap merekomendasikan mendesain dashboard sistem infromasi dimana nanti pada penelitian lanjutan bisa lakukan merancang suatu software 
aplikasi yang dapat mengatasi inefisiensi proses dimana lebih baik menggunakan software yang terintegrasi dengan sistem pelayanan konsumen dan sistem informasi produksi sehingga tujuan penelitian ini untuk mampu memangkas proses dan waktu yang tidak efisien bisa tercapai , sebagai media transformasi dari konvensional ke dalam bentuk digital, tampilan software aplikasi yang diusulkan dirancang menggunakan software aplikasi Balsamiq 4.1.2 dalam design user interface.

\section{Design user interface}

Perancangan dashboard software aplikasi pada penelitian ini merupakan bentuk usulan sebagai solusi dari tools proses bisnis yang diusulkan
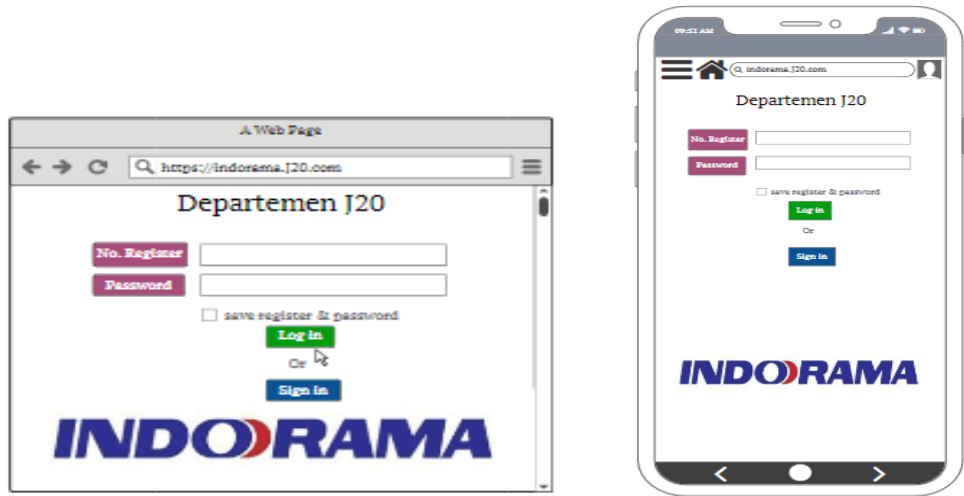

Gambar 5. Tampilan Menu Awal software aplikasi E-J20
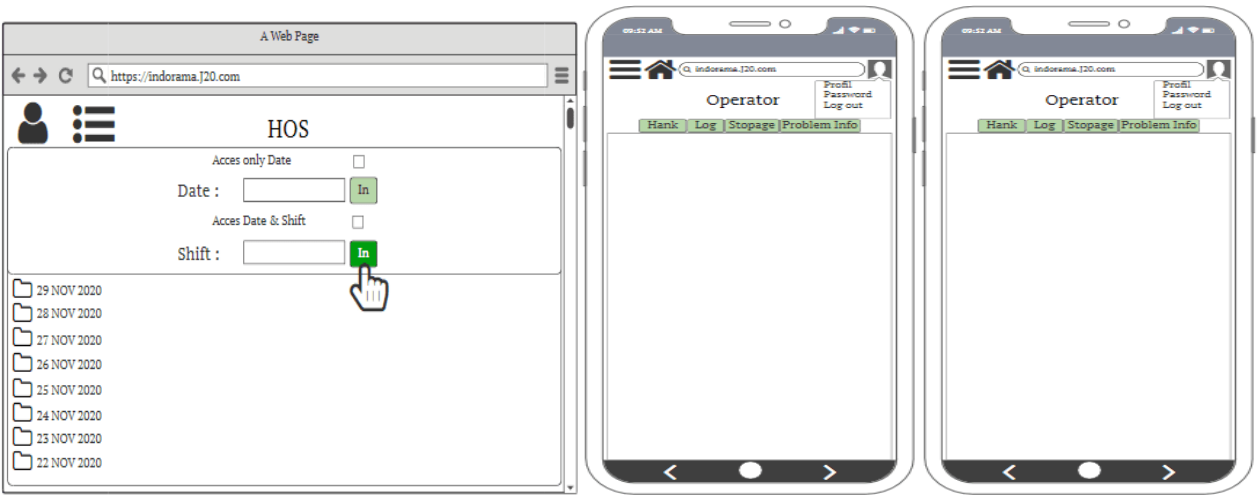

Gambar 6. Tampilan menu awal user
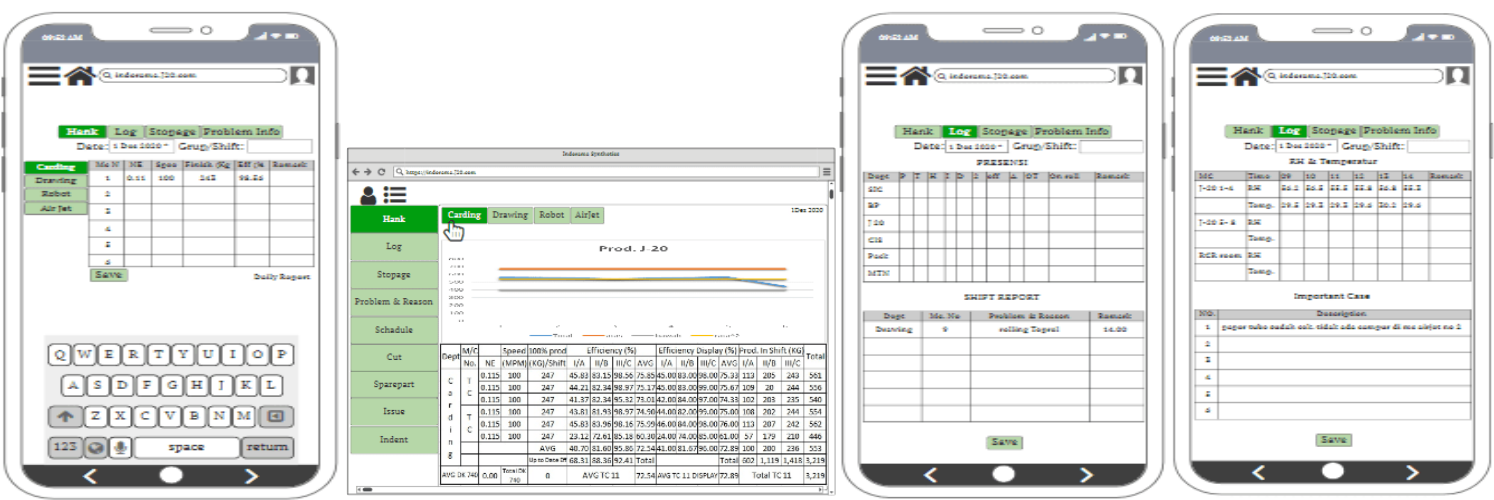

Gambar 7. Menu hank 
Jurnal Media

Teknik dan

Sistem Industri
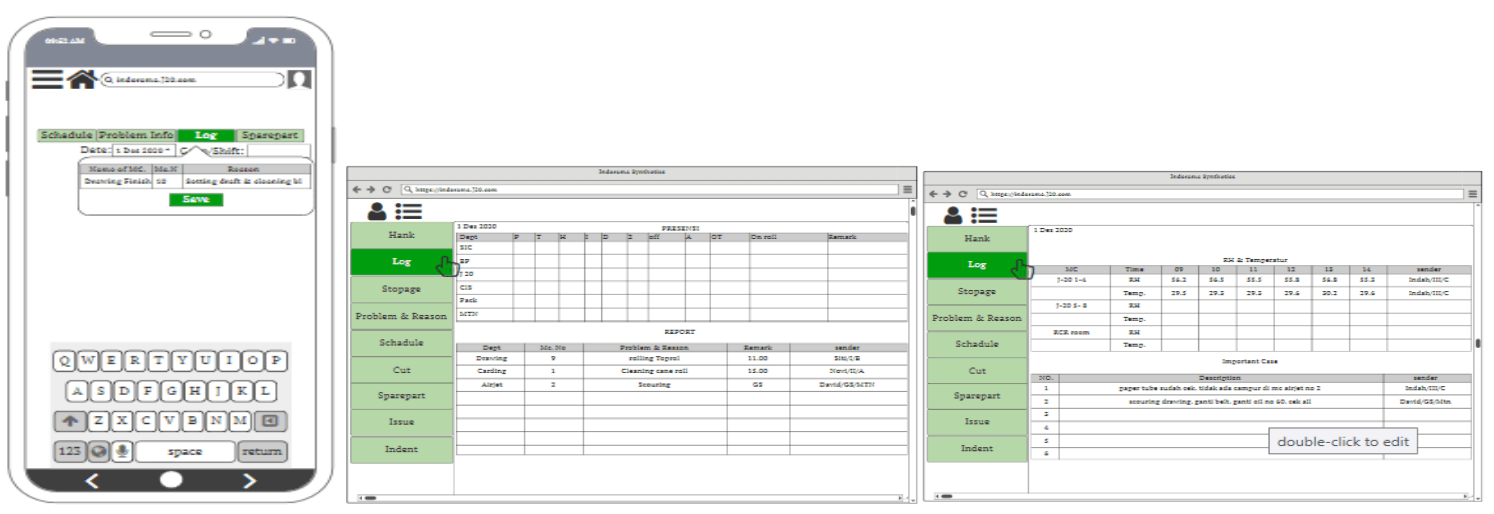

Gambar 8. Menu log

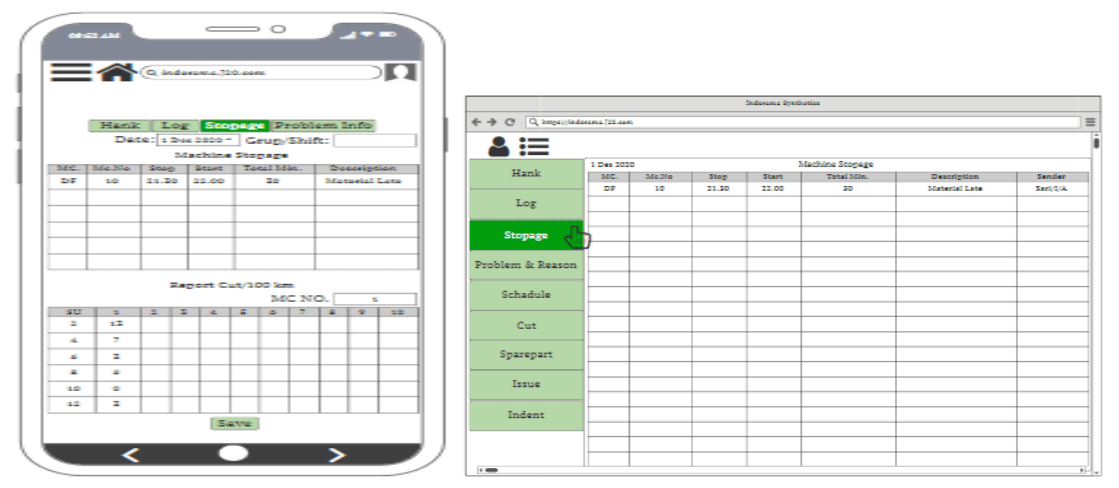

Gambar 9. Menu stoppage
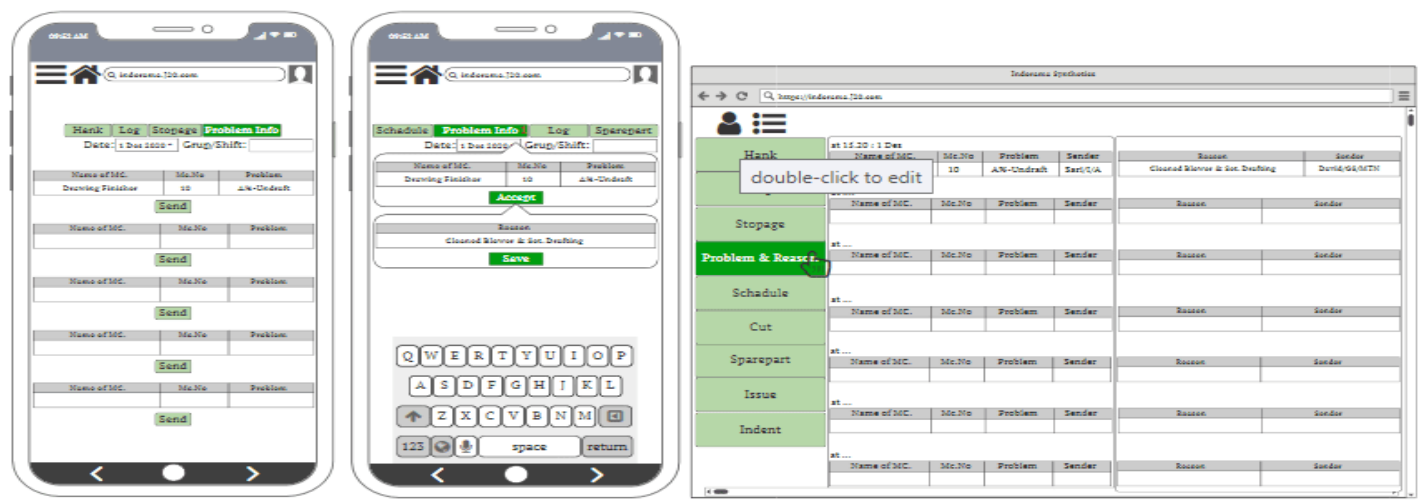

Gambar 10. Menu problem info dan reason
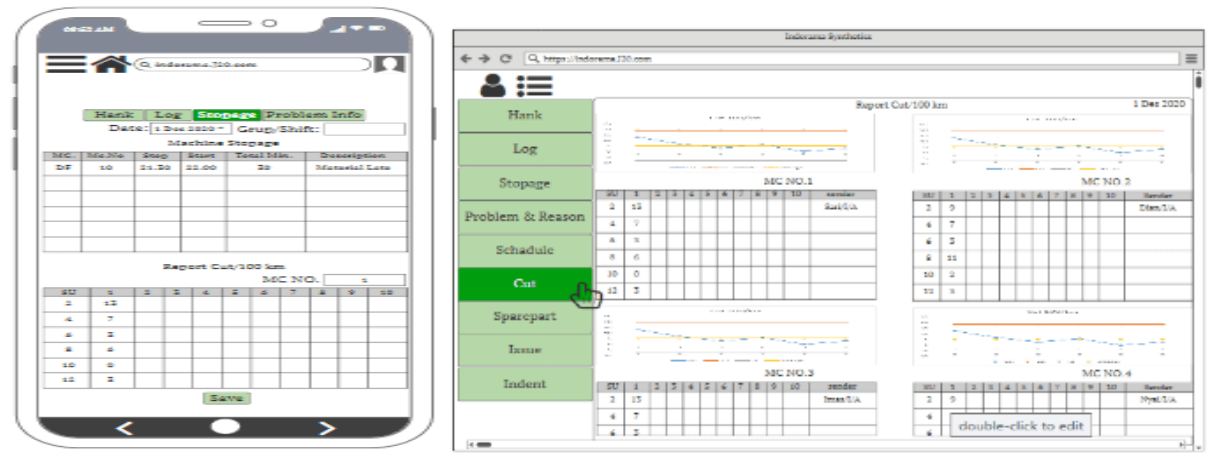

Gambar 11. Menu cut 

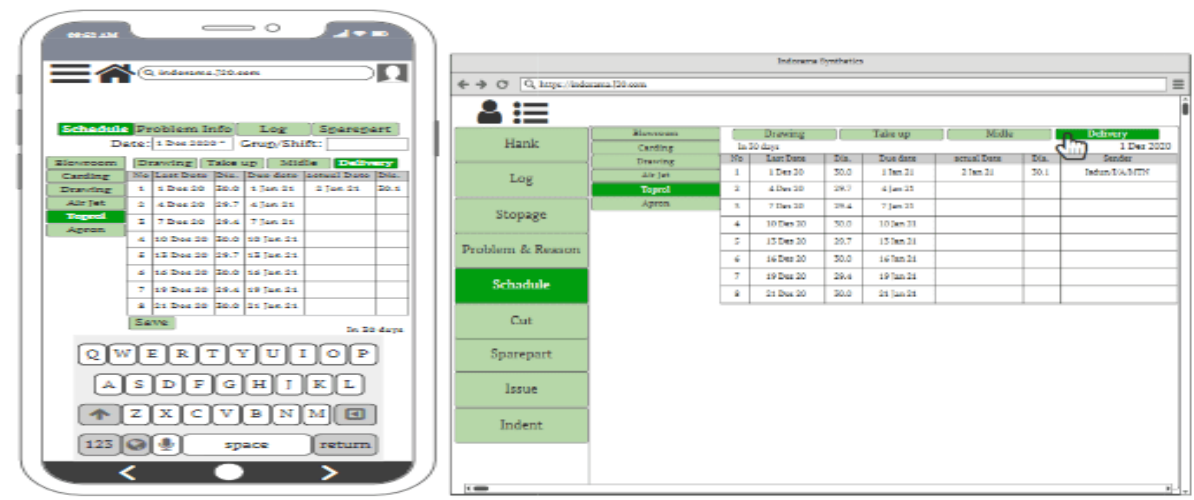

Gambar 12. Menu Schadule
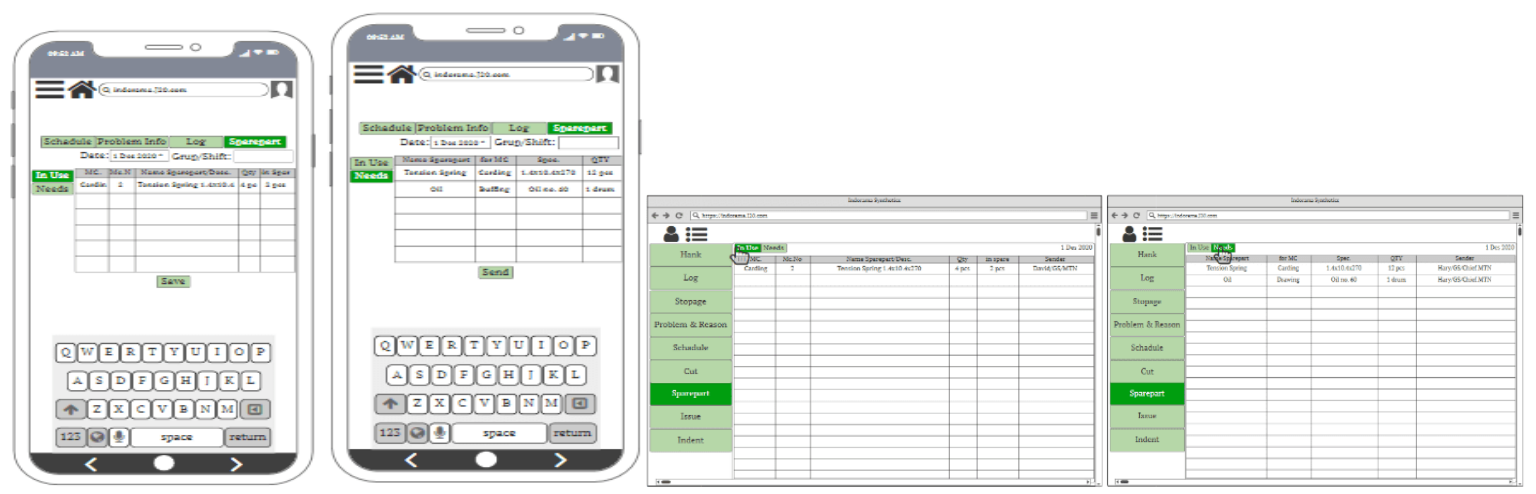

Gambar 13. Menu spare part

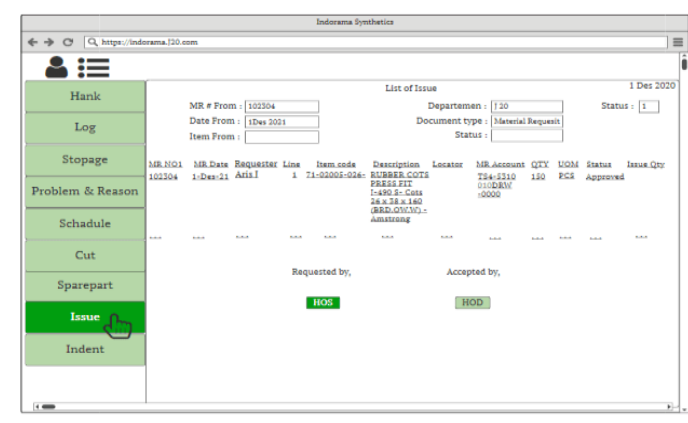

Gambar 14. Menu issue

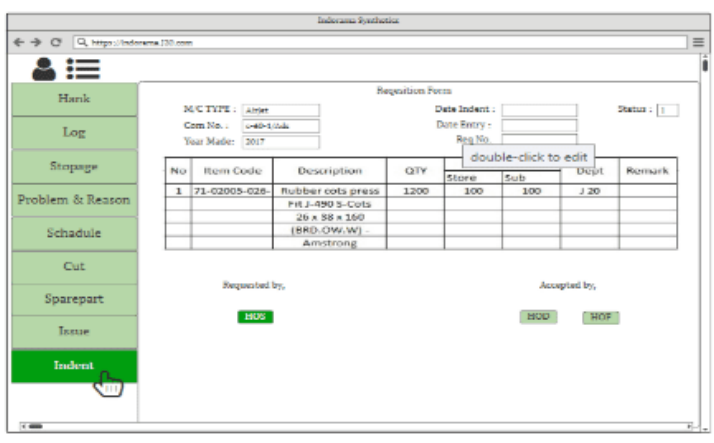

Gambar 15. Menu indent
E. Time Gap Analysis

TABEL VI

MATRIKS KESENJANGAN WAKTU PROSES

\begin{tabular}{ccc}
\hline Proses & Total waktu & Persentase \\
\hline Existing & 146 & $100 \%$ \\
Usulan & 51 & $34,9 \%$ \\
\hline \multicolumn{2}{c}{ Efisiensi waktu } & $\mathbf{6 5 , 1 \%}$ \\
\hline
\end{tabular}

TABEL VII

MATRIKS KESENJANGAN SIKLUS PROSES

\begin{tabular}{ccc}
\hline Proses & Total waktu & Persentase \\
\hline Existing & $24 \mathrm{~h} 27^{\prime}$ & $100 \%$ \\
Usulan & $12{ }^{\prime}$ & $0,8 \%$ \\
\hline \multicolumn{2}{c}{ Efisiensi Siklus } & $\mathbf{9 9 , 2 \%}$ \\
\hline
\end{tabular}

Pada matriks dapat ditelaah bahwa kesenjangan waktu proses existing dibandingkan dengan proses usulan, diharapkan dapat mencapai efisiensi proses sebesar $65,1 \%$ dan efisiensi siklus sebesar 99,2\%. Hal ini mengindikasikan bahwa terdapat perbaikan proses yang sangat signifikan. Dengan metode $B P R$ yang diusulkan, departemen J20 diharapkan dapat menigkatkan performansi kritis dalam mencapai produktivitas. 


\section{KESIMPULAN}

Hasil penelitian menunjukan adanya perubahan alur proses, jobdesk, eliminasi unit, serta usulan perancangan sistem informasi berupa software aplikasi sebagai tools dari proses bisnis usulan, sehingga diharapkan dapat diperoleh efisiensi waktu proses sebesar $65,1 \%$ dan waktu siklus sebesar $99,2 \%$ dari total waktu sebelumnya.

\section{UCAPAN TERIMA KASIH}

Terimakasih kepada ketua program studi Teknik Industri Sekolah Tinggi Teknologi Wastukancana atas dukunganya dalam penelitian ini, serta terimakasih kepada kepala bagian (HOS) Departemen produksi J20, atas selaku pembimbing lapangan pada penelitian ini.

\section{REFERENSI}

[1] H. J.Johanson, P. McHUGH, A. J. Pendlebury, and W. A. Whwller III, REKAYASA ULANG PROSES BISNIS, 1st ed. Jakarta: Binarupa Aksara, 1995.

[2] R. E. Indrajit, "Konsep dan Aplikasi Business Process Reengineering," ... Libr. Inf. Sci. Vol. ..., p. 249, 2014, [Online]. Available: http://books.google.com/books?hl=en\&lr=\&id= 8PJxrh_jUaQC\&oi=fnd\&pg=PA23\&dq=Busin ess+Process+Reengineering\&ots $=$ opoUemhR6 $\mathrm{q} \&$ sig=j9c0wRsa2-HzUMsiQqnxQHwv6io.

[3] En.wikipedia.org, "Business Process Model and Notation." 2020, [Online]. Available: https://en.wikipedia.org/wiki/Business_Process _Model_and_Notation.

[4] D. Burgess, Root cause analysis, vol. 22, no. 1. 2020.

[5] F. Kossak, C. Illibauer, V. Geist, J. Kubovy, C. Natschläger, and T. Ziebermayr, for BPMN 2. 0 , vol. 2, no. 12. 2010

[6] christopher k. Ahoy, customer-driven operation management. 2009.

[7] F. Caeldries, M. Hammer, and J. Champy, "Reengineering the Corporation: A Manifesto for Business Revolution," Acad. Manag. Rev., vol. 19, no. 3, p. 595, 1994, doi: $10.2307 / 258943$. 